Print ISSN: 2234-3040 / Online ISSN 2234-3059

doi:10.13106/eajbm.2018.vol8.no3.23

\title{
The Comparative Financial Performance of Outsourcing and Vertically Integrated Corporations
}

\author{
Shamima Khudadad*, Muhammad Tahir**, Ghulam Jan*** \\ Received: March 30, 2018. Revised: April 30, 2018. Accepted: July 15, 2018.
}

\section{Abstract}

Purpose - The purpose of this study is to analyze the comparative financial performance of outsourcing and vertically integrated corporations from Footwear and Apparel industry.

Research design, data, and methodology - Secondary data is collected from the published audited annual reports of the footwear and apparel corporations listed on stock exchanges globally. In the current study, 40 footwear firms have been opted that include 20 vertically integrated and 20 outsourcing firms. The sample is distributed into two groups based on threshold up-to 50 percent respectively outsourcing and vertically integrated companies. Sample independent $t$-test is applied to compare the financial performance of outsourcing and vertically integrated firms.

Results - Based on the investigation of 10 years' data of financial ratio, the results of the study show that there is significant difference between outsourcing and vertical integration strategy on return on assets, return on equity while insignificant difference has found with profit margin.

Conclusions - The findings of the current study indicates that there is significant difference between the financial performance of outsourcing and vertically integrated firms in terms of return on asset, return on equity and insignificant difference in terms of profit margin.

Keywords: Outsourcing Strategy, Vertical Integration, Financial Performance, Profitability Ratios.

JEL Classifications: J29, M10, M11.

\section{Introduction}

Proper strategy implementation results in higher profits, helps industries in different sectors gain and sustain competitive advantage. Organizations must decide whether to use outsourcing or vertically integrated strategy to compete with rivals. Additionally, a significant surge in the implementation of strategies has been found in multinational corporations over a decade. Several footwear and apparel corporations gained significant growth by the use of outsourcing strategy (e.g., Nike) relying totally on third-party

* First Author, University of Turbat, Pakistan.

E-mail: shamimakhudadad123@gmail.com

** Corresponding Author, School of Management, University Sains Malaysia and University of Turbat, Pakistan.

E-mail: tahirbadini@gmail.com

*** Co-Author, School of Management, University Sains Malaysia and University of Turbat, Pakistan.

E-mail: Ghulamjanmalik@gmail.com for manufacturing (Gilley \& Rasheed, 2000).

Outsourcing strategy emerged in the 19th century and increased with the development of businesses. This strategy has been defined by researchers, as a contractual agreement in long and short term to transfer activities and transfer of personnel to third parties (Rodríguez \& Robaina, 2006). Implementation of outsourcing strategy can bring many benefits to the corporations like value creation. Multinational firms started moving rapidly towards outsourcing strategy worldwide since the verdict of Eastman Kodak's in 1989 to outsource 100 percent of its information management from Institute of Business Management. The improvement of profitability, productivity along with goodwill has occurred after the decision. Outsourcing is recognized as a standardized strategy amongst United Nations corporations after the successful contractual agreements made by firms in information technology sectors. Beside this multiple key contract had been signed to outsource information in 1994 worth $\$ 11$ billion, in 1995, \$20 billion; and in 1996, $\$ 33$ billion (Loh \& Venkatraman, 1992). 
The global economy is changing where the emergent competition compels producers to focus towards higher productivity, efficiency, and flexibility due to outsourcing strategy that accelerated the competition in all industries (Martinez, 2010). The reduction of cost, economies of scale and improved quality can be achieved through outsourcing strategy that makes corporations more competitive in market (Williamson, 2008). In addition, outsourcing strategy empowers the corporation to concentrate on its core competencies. However, outsourcing strategy increases the expenditure in information technology (Kobelsky \& Robinson, 2010). Besides the benefits associated with outsourcing strategy, it has the risk of the dependency on the third party that may impact the satisfaction level, profitability along with the goodwill of the firms. Supplier problems are the core issues that can be main source of affecting the firm's reputation, dissatisfying customers and declining the profitability (Tibor, 2003). Outsourcing strategy rises the comparative demand for skilled labor, similarly 31-51 percent relative demand for skill labor has raised for United Nations manufacturing sector in the era of 1980. The firms shift their businesses to other countries in order to hire skilled labor with low wages that generates unemployment to their home country (Feenstra \& Hanson, 1996).

On the contrary, vertical integration strategy emerged in the gilded age by Andrew Carnegie in steel industry in order to retain market dominance. The firm uses latest technology along with vertical integration strategy to generate high revenue that attracts the business towards opting vertical integration strategy. Vertical integration strategy can be simply defined as all activities of production taking place within the corporation instead to purchase from independent companies in the market (Besanko, Dranove, Shanley, \& Schaefer, 2009) One of the leading companies (e.g., Zara) provides evidence that vertical integration strategy declines the holdup problem, increases the level of satisfaction of customers and reduces the cost that lead to surge in the profitability of the firms.

Outsourcing and vertical integration strategies both have different impacts on financial performance with different industries'. Outsourcing strategy has a positive influence on the financial performance in information technology industry, while a negative effect of outsourcing strategy is found on the financial performance in manufacturing industry (Bao, 2017; Loh \& Venkatraman, 1992). Some researchers argue regarding the positive influence of outsourcing and vertical integration strategy on IT industry and negative impact of outsourcing strategy and vertical integration strategy in manufacturing industry. A number of research have been done to evaluate the effect of outsourcing strategy and vertical integration strategy on firm's performance, innovation, and property right and so on (Agarwal \& Abid, 2013; Bustinza, Arias-Aranda, \& Gutierrez-Gutierrez, 2010; Woodruff, 2002). The unsolved impact of outsourcing and vertical integration strategies on financial performance put the management in a dilemma whether to select outsourcing strategy or vertical integration strategy to sustain the competitive market.

The complexity of background helps in taking better decision in future to choose the most favorable strategy. It is necessary for the managers and management to know the possible impact that can be brought by a decision of selecting outsourcing and vertical integration strategies. Although, the outsourcing and vertical integration strategies have been substantially analyzed in previous literature, there is lack of comparative studies found analyzing financial performance of outsourcing and vertically integrated corporations from footwear and apparel industries. Conversely, to the best of authors' knowledge almost no comparative research has found to analyze the financial performance of corporation on footwear and apparel industry. Thus, this study endeavors to fill this gap by comparing the financial performance of footwear and apparel firms using vertical or outsourcing strategies.

The rest of the paper is structured as follows: Section 2 explains the literature regarding the financial performance of Outsourcing and vertically integrated firms. Section 3 possess methodology that incudes data collection, sampling technique, operationalization of variables, explanations of variables and empirical model. Section 4 contains the detailed results and discussion and the conclusion, recommendations along with limitations are discussed in section.

\section{Literature Review and Hypothesis Development}

\subsection{Theoretical Background}

The theoretical literature examines the relationship between outsourcing and vertical integration strategy on the company's financial performance. The scholars have worked more on outsourcing strategy as compared to vertical integration strategy. However, no study can be found on the comparative analysis of financial performance on footwear and apparel sectors. Therefore, research-related to outsourcing strategy and vertical integrated strategy will be discussed separately as follows.

\subsubsection{Outsourcing strategy}

The accomplishment of tasks by an external business and signifies decision in order to refuse the internationalization of an activity (Gilley \& Rasheed, 2000). A provision of products, services as well as research and development activities by independent suppliers to the multinational organization (Bzhalava, 2015). Externalizing the non-core activities in which the third party possesses the expertise to produce at low cost, permits the multinational corporations to concentrate on its core competencies, generates higher revenue and compete in the race of sustainability in the market (Jiang, Frazier, \& Prater, 2006). Subcontracting those 
products which were formerly manufactured in house (Kakabadse \& Kakabadse, 2002). Virtually, all scholars reach the same conclusion regarding the definition of outsourcing strategy that firms should perform in house those activities in which they are specialized and subcontract those activities in which the firms do not have expertise to produce better than its competitors (Yang \& Huang, 2000). A well-organized outsourcing strategy improves the competitiveness along with creating value for the shareholder (Bryce \& Useem, 1998). The imperative strategy used by multinational organization in order to decline the total cost in the information technology sector and achieve access to the information technology facilities and capabilities which are not available in house (Kobelsky \& Robinson, 2010). This strategy may offer enhanced business performance in several dimensions like concentrating on core activities, rise greater flexibility, gaining access to talent and skills that ultimately improve the financial performance (Kakabadse \& Kakabadse, 2002). Enhancement in the competitiveness of the firms is being achieved in all industry particularly in information technology (Agrawal \& Haleem, 2013).

In contrast to outsourcing strategy's merits, the demerits include higher spending cost specifically, in information technology sector (Kobelsky \& Robinson, 2010). Profitability and productivity tend to remain same, no improvement occurs due to outsourcing strategy (Jiang \& Qureshi, 2006). Shifting power towards suppliers are the expected risk overcome by multinational firms. The critical expected risk of losing employees and goodwill of the corporation. The hidden cost and unrealized saving that emerges after adopting outsourcing strategy (Kakabadse \& Kakabadse, 2002). Lacity et al.(1995) cited 70 percent multinational American corporations are unsatisfied with the vendors (Kakabadse \& Kakabadse, 2002).

\subsubsection{Outsourcing strategy and Financial Performance}

Various scholars studied the relationship between outsourcing strategy and financial performances nevertheless they come up with different conclusions regarding their linkage between each other. The relationship between outsourcing strategy and financial performance is an unsolved issue because prior research results are contrasting with each other. The return on assets, return on investment and net profit margin are key indicator to measure the financial performance of the corporations in any industry.

\subsubsection{Return on Assets}

The competitive capabilities and financial performance of multinational organizations are influenced by the decision of outsourcing strategy. The return on assets has increased subsequently the decision of implementing the outsourcing strategy. The study indicates that a positive relationship exists between outsourcing strategy decision and return on equity The extent of outsourcing strategy that includes non-core function has a impact on firms financial performance along with non-financial performance of the corporations. The outcome of the research concludes that the return on assets ratio rises from 0.80 to 0.91 . Hence, it indicates a positive relationship of outsourcing strategy with the return on assets (Gilley \& Rasheed, 2000). Besides this Outsourcing strategy raises the profitability metric in term of bringing improvement in firm's financial performance of the companies. The scholar states that a positive relationship is found between outsourcing strategy and return on assets in term of increasing the return on assets in information technology (Agrawal \& Abid, 2013). In contrast to a positive correlation between outsourcing strategy and financial performance in case of return on assets, another study provides evidence that there is no significant relationship between service outsourcing and profitability metrics (Görg \& Hanley, 2004).

\subsubsection{Return on Equity}

The outsourcing strategy decision is positively correlated with return on equity that lead to an enhancement in the financial performance. The decision of outsourcing strategy declines the cost and generates higher returns for the multinational firms. Shareholders'value are raised through outsourcing strategy. Some studies indicate that there is a positive relationship between outsourcing strategy and return on equity. Although, a recent study found a negative relationship between outsourcing strategy on return on equity of the multinational organization (Agrawal \& Abid, 2013; Bustinza, Arias-Aranda, \& Gsutierrez-Gutierrez, 2010; Jiang \& Qureshi, 2006; Useem \& Bryce, 1998). Material outsourcing strategy has a positive relationship with profitability metrics that leads to the surge of revenue of the multinational corporations (Görg \& Hanley, 2004).

\subsubsection{Profit Margin}

The contractual agreement improves the financial performance of the firms in term of positively impacting the profit margin because the contractual agreement creates a value for the firms in case of allowing it to focus on the core activities of the corporation (Jiang \& Qureshi, 2006). Gorg and Hanley (2004) propose that the material outsourcing strategy increases the profit margin while service outsourcing strategy diminishes the profit margin of the multinational corporations. The scholar suggests that a substantial and positive relationship exists between outsourcing strategy and financial performance of the corporation that helps the firms to enhance its profitability ratio like net profit margin. The positive relationship of outsourcing strategy with profitability metrics relies on the optimal level of outsourcing strategy. Higher level of outsourcing strategy led towards a negative relationship with financial performance (Görg \& Hanley, 2004). On contrary there is no relationship between outsourcing strategy with net profit margin because neither it increases nor decreases 
in information technology sector (Agrawal \& Abid, 2013). The profitibility of the mulitnational firms declines owing to subcontracting (Kambara, 2013).

\subsubsection{Vertical integration Strategy}

The entire manufacturing of products, goods occurs in house in order to produce high quality products and improve the coordination within the firms along with satisfying the consumer (Kambara, 2013; Liu, 2016). The vertical integration economies decline the costs by eliminating the duplicate overhead cost. Improvement in coordination and reduction in the holdup problem or diminishing the inventories can be obtained by the corporations. Companies can get superior quality products through obtaining the control over quality in case of adaptation of vertical integration strategy. Shareholders wealth can be retained merely owing to vertical integrated strategy. It neglects the time-consuming activities like negotiating contracts. Multinational firms can make credibility of entirely new products as well as get an opportunity for the purpose of differentiating products (Harrigan, 1994). Vertically integrated firm can double the marginalization in case of adopting the franchises. It permits the single vertically integrated corporation to compete domestically and internationally in term of brand competition against its competitor and earn higher amount of revenue (Murry, 2015). The removal of hold up is achieved that leads to the reduction of markdown (Liu, 2016). Multinational corporations are moving towards vertical integration strategy in order to achieve competitive edge. The vertically integrated corporations provide high quality products and sell at lower price as compared to outsourcing firms. It eliminates the intermediaries profiting from it that leads to double the marginalization and enhance the investment in term of quality improvement of the product (Korneyko \& Latkin, 2015). However, the need of overhead increases the cost of the vertical integration strategy. The firm cannot engross fluctuations due to the absence of subcontractors. The non-well organized vertical integration strategy generates the cost and dissatisfies the consumers (Harrigan, 1994). Vertical integration strategy does not make efficiency through decreasing the transaction cost related to market exchange (Williamson, 1971).

\subsubsection{Vertical Integration Strategy and Financial Performances}

The multiple studies have been conducted in order to gauge the effect of vertical integration strategy on financial performance. Prior studies indicate that a mix relationship was found between vertical integration strategy and financial performance of the corporations. Preceding literature comes up with the unsolved conclusion regarding their relationship. In order to analyze the financial performance of the vertically integrated firms return on assets, return on equity and net profit margin are utilized.

\subsubsection{Return on Assets}

Prior studies represent a positive relationship between vertical integration strategy and financial performance of the corporations. The return on equity is positively correlated with financial performance in banking sector. Vertical integration strategy raises the profitability of the firms from dairy farm sector. Hence, a positive relationship exists between vertical integration strategy and return on assets (Gellrich, Hackethal, \& Holzhäuser, 2005; Gillespie, Nehring, Sandretto, \& Hallahan, 2010). Investment incentive, innovation raises that leads to an improvement on the firm's financial performance as well as influencing positively the return on equity (Liu, 2016). Conversely, another research demonstrates no significant relationship exists between vertical integration strategy and return on equity (Christensen \& Montgomery, 1981).

\subsubsection{Profit Margin}

Liu ( 2016) provides evidence that the vertical integration strategy increases the profitability of the firm along with the innovation of the corporation. Edwards et al. (2000) examines the relationship between vertical integration strategies with profitability in two different time-period. The positive relationship found with the profitability in the time period of 1992 while a negative relationship is found between vertical integration strategies with profitability in the time period of 1972 that depicts a significant relationship existing between vertical integration strategies with profit margin. Conversely, The moderate level of vertical integration strategy has no influence on multinational corporation's profit margin that indicates that no relationship exists between moderate level of vertical integration strategy on profit margin (Levin, 1981).

Following are the hypotheses of this research study:

$<\mathrm{H} 1>$ There is significant difference between the return on investment of outsourcing and vertically integrated firms.

$<\mathrm{H} 2>$ There is a significant difference between the return on equity of outsourcing and vertically integrated firms.

$<\mathrm{H} 3>$ There is a significant difference between profit margin of outsourcing and vertically integrated firms.

\section{Methodology}

\subsection{Data Collection Method}

The secondary method has been used for the collection of data. Data is collected from the published audited annual reports of the footwear and apparel corporations listed on stock exchanges globally. In order to surge the reliability and validity of the results, data from audited financial statements of the corporations were used. The selected 40 
footwear companies including 20 vertical integrated firms and 20 outsourcing firms for the period of 2007-2016 are the sample for this study. The firm that outsource or vertically integrated up-to 50 percent its operation is sample for the comparative study.

\subsection{Sampling Technique}

The fortune 500 listed companies and annual report.com are the source for the selection of footwear and apparel corporations. This pattern of selecting data is accessible and cost effective. According to ICIS code the footwear and apparel have treated as a single industry. The footwear and apparel firms are the population for this comparative study based on the given information of footwear and apparel companies, available on their official website. The sample is distributed on two groups based on threshold of up-to 50 percent of outsourcing and vertically integrated multinational footwear and apparel corporations. The period of 2007-2016 have been selected for a business cycle accomplish in ten years.

\subsection{Operationalization of Variables}

The profitability ratio such as return on assets, return on equity and profit margin are the most imperative ratio for the purpose of analyzing the financial performance of the firms. Hence, these important variables are used in the comparative study. The Operationalization of variables are given below.

<Table 1> Profitability Metrics

\begin{tabular}{|c|c|c|}
\hline Variables & Description/proxy & Measurement \\
\hline ROA & Return on assets ratio & $\begin{array}{c}\text { Net profit after taxes / total } \\
\text { assets. }\end{array}$ \\
\hline ROE & Return on equity ratio & $\begin{array}{c}\text { Net profit after taxes } \\
\text { /shareholder's equity. }\end{array}$ \\
\hline PM & Profit margin ratio & $\begin{array}{c}\text { Net profit after taxes / net } \\
\text { sales. }\end{array}$ \\
\hline
\end{tabular}

\subsection{Statistical Model}

Financial ratios are one of the substantial direct methods used widely in the analysis of financial performance. As it was mentioned in previous research that profitability ratio is the most imperative criterion for evaluating of firm's performance. The profitability ratio has been used to evaluate the financial performance (Bao, 2017). In this comparative study the statistical tool Independent sample t-test is used to gauge the significant difference in financial performance between outsourcing and vertically integrated footwear and apparel corporations. Independent sample t-test possess two groups of subjects in an experiment where both groups of subjects are not performing in a similar condition in an experiment in this case the independent sample t-test is used (Lumley, Diehr, Emerson, \& Chen, 2002). Furthermore, in this study the financial performance of outsourcing and vertically integrated firm are being evaluated that depicts two different subject of group are performing in a dissimilar condition. Hence, independent sample t-test is an appropriate test for this study. In addition to, the main limitation on an independent sample t-test for association has not a distributional one nevertheless, whether identifying and assessing a difference in the mean of the outcome response the scientific query on a hand (Lumley, Diehr, Emerson, \& Chen, 2002). Moreover, the independent sample $t$ test was used in preceding researches in order to find the mean of the sample from unrelated group (Baldi \& Long, 2001) (Ellis, Daniels, \& Jauregui, 2010). Stata package is used for the model estimation.

\section{Results and Discussion}

\subsection{Independent Sample T-Test Analysis}

The current study aims to compare the financial performance of outsourcing and vertically integrated footwear firms. The sample is selected from the footwear industry that includes 20 outsourcing firms and 20 vertically integrated firms for the period of 2007 to 2016 to analyze the financial performance by using different profitability metrics. The footwear and apparel corporation are distributed on two group based on threshold of up-to 50 percent in the financial annual report of the companies, available in their official website. The return on assets, return on equity and profit margin are the main profitability ratio that helps to examine the financial performance of the firms. The independent sample t-test is utilized in this study because the groups are unrelated with each other. In order to get reliable results, the Stata software is used. The mean, standard deviation $t$ statistics and $p$-value of outsourcing and vertically integrated corporation's profitability ratios from footwear industry are given below that highlight results that is achieved by using independent sample t-test on Stata.

<Table 2> Independent Sample T- Test

\begin{tabular}{|c|c|c|c|c|c|}
\hline & Strategy & Mean & $\begin{array}{l}\text { Standard } \\
\text { deviation }\end{array}$ & $\begin{array}{c}\text { T(statistics) } \\
\text { df }\end{array}$ & p-value \\
\hline \multirow{2}{*}{$\begin{array}{l}\text { Return on } \\
\text { assets }\end{array}$} & Outsourcing & 7.33 & 6.79 & 2.14 & \multirow[b]{2}{*}{0.0164} \\
\hline & $\begin{array}{c}\text { Vertical } \\
\text { integration }\end{array}$ & 6.06 & 4.98 & (398) & \\
\hline \multirow{2}{*}{$\begin{array}{l}\text { Return on } \\
\text { equity }\end{array}$} & Outsourcing & 12.90 & 13.45 & 1.83 & \multirow[b]{2}{*}{0.0339} \\
\hline & $\begin{array}{c}\text { Vertical } \\
\text { integration }\end{array}$ & 10.96 & 6.70 & (398) & \\
\hline \multirow[b]{2}{*}{ profit margin } & Outsourcing & 8.48 & 7.80 & -5.01 & \multirow[b]{2}{*}{1.0000} \\
\hline & $\begin{array}{c}\text { Vertical } \\
\text { integration }\end{array}$ & 13.84 & 12.95 & (398) & \\
\hline
\end{tabular}


The <Table 2> is depicting the mean, standard deviation along with value of outsourcing corporations and vertical integrated corporations separately. The mean of the return on assets of outsourcing corporation is 7.333025 and 6.05705 of vertical integration that shows the mean of outsourcing is higher in comparison of vertical integration. The standard deviation of return on assets for outsourcing corporation is 6.787266 and 4.984443 vertically integrated firms that signifies the business risk is higher in outsourcing companies as compared to the vertical integrated companies. The P-value 0.0164 is depicting that there is a significant difference between outsourcing strategy and vertical integrated strategy in terms of return on assets of the corporations. On the other hand, the mean of return on equity for outsourcing firms and vertically integrated firms have occurred respectively is 12.9037 and 10.95885 which indicates a higher difference between the outsourcing firms and vertical integrated firms. The standard deviation for outsourcing firm is 13.44518 and 6.702184 that represents the business risk is lower in vertical strategy in comparison of outsourcing strategy. The p-value is 0.0339 for strategies represents that there is a difference between outsourcing and vertical integration on return on equity. The mean of net profit margin for outsourcing firm along with vertically integrated firm respectively 8.4788 and 13.83658 that symbolize higher mean for firm vertically integrated then outsourcing corporation. Additionally, the standard deviation of outsourcing organization is 7.800825 and 12.94947 for vertically integrated organization that represents the lower volatility for outsourcing firms in comparison of vertically integrated firm. The $p$-value is 1.0000 shows that no significant relationship is found between outsourcing and vertical integration on profit margin. The $t$ statistics is depicting that the return on assets, return on equity are significant statistically. The $\mathrm{t}$ statistics of profit shows that there is no significant difference between outsourcing and vertically integrated firms in terms of profit margin.

\subsection{Theoretical perspective and Modern Manager linking with Transaction Cost Economies Theory.}

The transaction cost theory was postulated by Coase Ronald in 1937 and further refined by Williamson in 1970s and 1980s. Predominantly, production cost along with transaction cost are being focused by transaction cost theory. Furthermore, successful firms maintain their position by superior balance of production against transaction cost theory. Therefore, the main focus of the corporation is on the production and efficient management of the corporation (Gellrich, Hackethal, \& Holzhäuser, 2005). The transaction cost economies theory proposes that corporations will manage itself in a manner in order to reduce the transaction costs (Lamminmaki, 2011). The inefficiencies increasing from the risk of opportunism that lead to high the cost of transaction in the business market (Williamson, 1971). The opportunistic attitude has surged the cost for every single the transaction. Therefore, the component that contain high transaction cost should be identified and produce internally instead of outsourcing from the third party (Delios \& Henisz, 2000). Furthermore, the vertical integration decision relies on the transaction cost; that are under markets along with contract with corporations. Hence, transaction is the major unit in order to analyze the transaction cost of economies (Williamson, 1975). The outsourcing strategy lower the production cost nevertheless, higher transaction cost along with risk increasing from monitoring, negotiating and contracting with third party (Cheon, Grover, \& Teng, 1995). The transaction cost theory emphasize that critical and specific product should be outsource from the third party that has the expertise to produce it better in comparison of integrated firm while the non-specific and critical product should be produce internally (Gellrich, Hackethal, \& Holzhäuser, 2005). Strategies has an impact on the financial performance of the firm and it is an important for modern manager to analyze the holistic view of strategies respectively, outsourcing and vertical integrated strategy in order to opt the best strategy that helps them to achieve the long term goal of the firms in a better way in comparison to its rivals. This study helps mangers in footwear and apparel industry to choose the strategy that fit in industry that ultimately enhance the sustainability and profitability of the firm.

\subsection{Discussion}

On the basis of independent sample t-test results the return on asset of outsourcing firms is greater compared to return on asset of vertical integrated footwear and apparel firms. The vertical integrated firms have larger portion of assets as compared to outsourcing firms. Hence, the vertically integrated footwear and apparel corporations depict a lower return on assets then outsource based firms. Agrawal et al. (2013) has piloted a research on information technology sector to analyse the impact of outsourcing on the financial performance of the information technology companies. The research proves that outsourcing increases the return on assets of the information technology based on firms. In addition, the vertical integrated corporations have higher number of shareholders in footwear and apparel industry. Therefore, the empirical result depicts that outsource based footwear and apparel corporations have higher return on equity than vertically integrated footwear and apparel corporations. On the contrary prior researchers find that outsourcing declines the return on equity (Useem \& Bryce, 1998; Bustinza, Arias-Aranda, \& Gutierrez-Gutierrez, 2010; Agrawal \& Abid, 2013; Jiang \& Qureshi, 2006). According to the results the profit margin of outsource base footwear and apparel corporations have lower profit margin than vertically integrated companies because the intial cost of vertically integrated firms is higher as compared to 
outsourcing firms but in long term outsourcing footwear and apparel corporations have high cost of transaction that declines the profit margin. The vertically integrated companies reduces the hold up problem that leads to reduction in cost and generate higher profit margin (Murry, 2015). Zara the flagship of Inditex companies and vertically integrated has achieved lower cost by declining the holdup problem in the competitive market (Ferdows, Lewis, \& Machuca, 2005). This research gives an insight view regarding the outsourcing and vertical integration linking with footwear industry through a comparison of strategy within footwear industry in order to find the strategy which helps the corporation to sustain its position in the market and confiscating their dilemma. This research recommends to the managers that by opting outsourcing strategy the firm can achieve higher return on assets and return of equity as compared to vertically integrated firm in footwear and apparel industry.

\section{Conclusion and Recommendation}

Several studies have been conducted by scholars taking different industry to evaluate the impact of outsourcing strategy and vertical integration strategy on the financial performance and non-financial performance of the firms. However, no study is conducted on the comparative analysis of outsourcing and vertically integrated firms on the financial performance from footwear and apparel industry. This study indicates that two most rapidly increasing strategies are vertical integration strategy and outsourcing strategy whether they effect on the financial performance of the footwear firms or not. Financial performance can be measured through proxies like return on assets, return on equity and profit margin. The motive behind conducting this comparative study is to solve the managerial problem in shape of eliminating the dilemma that exists in the footwear and apparel industry in term of selecting the strategy. The selection of pertinent strategy helps the firm to generate higher profit and sustain its position in the business arena. The 40 footwear corporations that include 20 outsourcing corporations and 20 vertical integrated corporations have been selected for comparison of the financial performance with the help of profitability ratio. The footwear and apparel companies that outsource up-to 50 percent and the firms that are vertically integrated up-to 50 percent of its production in house are the sample for this comparative study. The data has been collected through audited annual reports in order to eliminate non-reliability of data. The independent simple t-test is used in Stata software to get reliable results. The results of the independent $t$ test give evidence that there is a significance difference between outsourcing and vertical integration in term of return on assets and return on equity while result shows insignificant impact of profit margin. The current comparative study provides evidence that outsourcing is better in terms of increasing the return on asset along with return on equity compared to vertically integrated firms.

\subsection{Limitations}

This comparative research contains few limitations likewise; the sample size is quite small as only 40 footwear corporations have been taken from the population that may not cover the need of the current comparative study. This study is emphasizing on a single industry.

\subsection{Recommendations}

This research recommends future research in two dimensions: guidelines to the researchers. First this comparative study possesses certain imperative recommendations for instance, researchers can work on a similar comparative study of financial performance of outsourcing and vertically integrated corporations by using multi- industries. Second, the future studies can also be conducted by using different variable. For example, future research can be piloted on the financial position of corporations by using different ratios such as liquidity ratio, debt ratio, and efficiency ratio and so on.

\section{References}

Agrawal, P., \& Haleem, A. (2013). The impact of the outsourcing of IT on firm performance: An empirical study. International Journal of Management, 30(3), 121-139.

Adelman, M. A. (1955). Concept and statistical measurement of vertical integration. In Business Concentration and Price Policy (pp.281-330). Princeton, NJ: Princeton University Press. Retrieved March 1, 2018 from http://www.nber.org/chapters/c0965

Bustinza, O. F., Arias-Aranda, D., \& Gutierrez-Gutierrez, L. (2010). Outsourcing, competitive capabilities and performance: An empirical study in service firms. International Journal of Production Economics, 126(2), 276-288.

Bao, H. (2017). Evaluation of pre and post DemergerMerger performance: Using ABN AMRO Bank as an example. International Journal of Economics and Finance, 9(2), 196.

Bzhalava, L. (2016). The Innovative performance of R\&D Outsourcing. Journal of Innovation Management, 3(4), 70-95.

Bryce, D. J., \& Useem, M. (1998). The impact of 
corporate outsourcing on company value. European Management Journal, 16(6), 635-643.

Belso-Martinez, J. A. (2010). Outsourcing decisions, product innovation and the spatial dimension: evidence from the Spanish footwear industry. Urban Studies, 47(14), 3057-3077.

Besanko, D., Dranove, D., Shanley, M., \& Schaefer, S. (2009). Economics of Strategy. (5th ed.). Hoboken, NJ: John Wiley \& Sons Inc.

Baldi, P., \& Long, A. D. (2001). A Bayesian framework for the analysis of microarray expression data: Regularized t-test and statistical inferences of gene changes. Bioinformatics, 17, 509-519.

Christensen, H. K., \& Montgomery, C. A. (1981). Corporate economic performance: Diversification strategy versus market structure. Strategic Management Journal, 2(4), 327-343.

Cheon. J. M., Grover, V., \& Teng, T. C. James (1995). Theoretical Perspectives on the Outsourcing. Journal of Information Technology, 10, 209-220.

Dawes, J. (1999). The relationship between subjective and objective company performance measures in market orientation research: Further empirical evidence. Marketing Bulletin-Department of Marketing Massey University, 10, 65-75.

Delios, A., \& Henisz, W. (2000). Japanese Firms' Investment Strategies in Emerging Economies. Academy of Management Journal, 43(3), 305-23.

Espino--Rodríguez, T. F., \& Padrón--Robaina, V. (2006). A review of outsourcing from the resource--based view of the firm. International Journal of Management Reviews, 8(1), 49-70.

Ellis, Y., Daniels, B., \& Jauregui, A. (2010). The effect of multitasking on the grade performance of business students. Research in Higher Education Journal, 8(1), 1-10.

Edwards, K., Jackson, J., \& Thompson, H. (2000). A note on vertical integration and stock ratings of oil companies in the U.S. The Energy Journal, 21(2), 145-151.

Feenstra, R. C., \& Hanson, G. H. (1996). Globalization, outsourcing, and wage inequality. American Economic Review, 86(2), 240-245.

Ferdows, K., Lewis, M. A., \& Machuca, J. A. (2005). Zara's secret for fast fashion. Harvard Business Review, 82(11), 98-111.

Gillespie, J., Nehring, R., Sandretto, C., \& Hallahan, C. (2010). Forage outsourcing in the dairy sector: The extent of use and impact on farm profitability. Agricultural \& Resource Economics Review, 39(3), 399-414.

Görg, H., \& Hanley, A. (2004). Does outsourcing increase profitability?. The Economic and Social Review, 35(3), 267-288.

Gilley, K. M., \& Rasheed, A. (2000). Making more by doing less: An analysis of outsourcing and its effects on firm performance. Journal of Management, 26(4), 763-790.

Gellrich, T., Hackethal, A., \& Holzhäuser, M. (2005). Vertical integration and bank performance. In: Proceedings of the INFORMS Annual Meeting, New Orleans, USA

Harrigan, K. R. (1984). Formulating vertical integration strategies. Academy of Management Review, 9(4), 638-652.

Hanif, M., Tariq, M., Tahir, A., \& Momeneen, W. (2012). Comparative performance study of conventional and Islamic banking in Pakistan. International Research Journal of Finance \& Economics, 83, 63-72.

Ika, S. R., \& Abdullah, N. (2011). A comparative study of financial performance of Islamic banks and conventional banks in Indonesia. International Journal of Business and Social Science, 2(15), 199-207.

Jiang, B., Frazier, G. V., \& Prater, E. L. (2006). Outsourcing effects on firms' operational performance: An empirical study. International Journal of Operations \& Production Management, 26(12), 1280-1300.

Kobelsky, K. W., \& Robinson, M. A. (2010). The impact of outsourcing on information technology spending. International Journal of Accounting Information Systems, 11(2), 105-119.

Kremic, T., Icmeli Tukel, O., \& Rom, W. O. (2006). Outsourcing decision support: A survey of benefits, risks, and decision factors. Supply Chain Management: An International Journal, 11(6), 467-482.

Kakabadse, A., \& Kakabadse, N. (2002). Trends in outsourcing: Contrasting USA and Europe. European Management Journal, 20(2), 189-198.

Kambara, H. (2013). Production outsourcing and firm performance: An empirical analysis of Japanese manufacturers. Journal of Business Studies Quarterly, 5(1), 1-13.

Kosmidou, K. (2008). The determinants of banks' profits in Greece during the period of EU financial integration. Managerial Finance, 34(3), 146-159.

Korneyko, O. V., \& Latkin, A. P. (2015). Integration of fishery enterprises in the Primorsky region: Economic rationales and ways of their realization. Mediterranean Journal of Social Sciences, 6 (5 S3), 118. Retrieved March 1 , 2018 from Doi:10.5901/mjss.2015.v6n5s3p118. 
Levin, R. C. (1981). Vertical integration and profitability in the oil industry. Journal of Economic Behavior \& Organization, 2(3), 215-235.

Liu, X. (2016). Vertical integration and innovation. International Journal of Industrial Organization, 47, 88-120.

Loh, L., \& Venkatraman, N. (1992). Diffusion of information technology outsourcing: Influence sources and the Kodak effect. Information Systems Research, 3(4), 334-358.

Lumley T, Diehr, P., Emerson, S., \& Chen, L. (2002). The importance of the normality assumption in large public health data sets. Annual Rev Public Health, 23, 151-169.

Lamminmaki, D. (2011). An examination of factors motivating hotel outsourcing. International Journal of Hospitality Management, 30(4), 963-973.

Maddigan, R. J., \& Zaima, J. K. (1985). The profitability of vertical integration. Managerial and Decision Economics, 6(3), 178-179.

Murry, C. (2015). Advertising in vertical relationships: An equilibrium model of the automobile industry. Retrieved May 22, 2017 from http://dx.doi.org/10.2139/ssrn.2549247

Pal, K., \& Soriya, S. (2012). IC performance of Indian pharmaceutical and textile industry. Journal of Intellectual Capital, 13(1), 120-137.

Pal, Shrabanti (2012). Comparative study of financial performance of Indian steel companies under globalization. International Journal of Accounting and Financial Management Research, 2(4), 1-8.

Shah, R., \& Goldstein, S. M. (2006). Use of structural equation modeling in operations management research: Looking back and forward. Journal of Operations Management, 24(2), 148-169.

Sayilgan, G., \& Yildirim, O. (2009). Determinants of profitability in Turkish banking sector: 2002-2007. International Research Journal of Finance and Economics, 28, 207-214.

Williamson, O. E. (2008), Outsourcing: Transaction cost economics and supply chain management Journal of Supply Chain Management, 44(3), 5-16.

Woodruff, C. (2002). Non-contractible investments and vertical integration in the Mexican footwear industry. International Journal of Industrial Organization, 20(8), 1197-1224.

Williamson, O. E. (1971). The vertical integration of production: Market failure considerations. The American Economic Review, 61(2), 112-129.

Williamson, O. E. (1975). Markets and hierarchies: Analysis and Antitrust Implications. New York: Free Press.

Yang, C., \& Huang, J. B. (2000). A decision model for IS outsourcing. International Journal of Information Management, 20(3), 225-23. 